\title{
MEMETIC POOL AS A NEW APPROACH IN SERVICE QUALITY ANALYSIS
}

\author{
KRZYSZTOF STEPANIUK
}

\begin{abstract}
A B S TR A C T
This paper attempts to decompose, as well as perform a quantitative and qualitative analysis of the way to externalize the perception of the accommodation service. The research material consisted of the opinions of users of accommodation facilities, located in the vicinity of the twelve selected national parks in Poland. It was assumed that the reflection of the perception of the quality of the service process is the transfer of intangible content related to the service itself, which can be externalized, among other things, through entries in social networks.

The study was conducted based on the theory of memes as cultural information carriers. According to this theory, in such a transmission, it is possible to distinguish certain components, which can be defined as memes. Therefore, it is possible to analyse and track their presence, transfer, as well as incidence. A memetic pool was constructed using the assumptions of the perceptual-cognitive model of the formation of the tourism image. It was a direct expression of the mental changes of the recipient, resulting from the use of the service.

Studies of this type are intended to optimize the design of services in terms of building positive relationships on the line service provider-customer. At the same time, they allow for a slightly different, evolutionary approach to analyses, concerning the formation of the image of the service provider, as well as forming the expectations of service recipients.
\end{abstract}

KEY WORDS

accommodation service, service quality perception, meme theory, meme transfer, User Generated Content, memetic pool formation

DOI: 10.1515/emj-2016-0037
Corresponding author:

Krzysztof Stepaniuk

Bialystok University of Technology, Faculty of Management, Department of Tourist Economy, Poland

e-mail: k.stepaniuk@pb.edu.pl

\section{INTRODUCTION}

The systemic approach to service quality refers to three basic components, i.e. the quality of input (the competence of employees providing a service, the circumstances of the service), process quality (interactions between the staff providing a service and the recipient), and the quality of output (changes in the physical and mental state of a recipient, resulting from the consumption of a service), (Urban, 2007; Juran, 1992 based on: Johnson et al. (1995) as well as Lehtinen \& Lehtinen (1991).

The customer perception of the quality of service summarizes his/her expectations with the actual effects of the consumption of the service. From this perspective, the decomposition of the perception of 
the quality of service, in terms of the quality process, provides a chance to extract quantitative and qualitative parameters (attributes) that make up the image of the service. These parameters are reflected in the mental image (and its externalization) of the quality of the service by the customer. This externalization, on a wider scale, can accumulate in the form of a set of defined and structured attributes. The thus obtained package of quantitative and qualitative characteristics can be used in a variety of ways. Firstly, during the design or modification of the service, it is possible to emphasize the elements most frequently perceived by the recipients, and also introduce new elements. Secondly, by emphasizing the service and its promotion during the planning stage, it is possible to build and manage certain expectations for the service. Extensive possibilities of conducting research from this perspective are provided by the application of the theory of memes (Dawkins, 1976, 1982).

The main scientific objective of the study was to demonstrate the possibility of building a memetic pool relating to the method of decoding the perception of service quality, using the example of the quality of the accommodation service.

\section{LITERATURE REVIEW}

\subsection{MEME THEORY}

Memes are the carriers of cultural information (Dawkins, 1976). They are the cultural analogue of genes. They shape attitudes, styles, behaviour, ways of dressing, and the manner of self-expression. Memes spread in the community through imitation or copying (Blackmoore, 2000). Because of this feature, it is possible to refer to them as replicators (Ball, 1984). Replicators exist and reproduce themselves through social interactions, passing from person to person, from brain to brain (Gabora, 2013). A slightly different viewpoint, associated with the viral approach to the transfer of replicators has been presented by Wang \& Wood (2011). The subsequent properties of replicators are (Dawkins, 1982; Gabora, 2013):

- Longevity - it survives long enough to replicate, or make copies of itself;

- Fecundity - at least one version of it can replicate;

- Fidelity - even after several generations of replication, it is still almost identical to the original.

Knobel \& Lankshear (2007) divide memes into less and more "expansive". The incidence of the effects of more expansive memes will be significantly higher in the analysed group than that of the less expansive ones. Memes compete for the "existence" in the population. The most popular ones, i.e. the ones most commonly used by an individual or social group are visible in the form of specific behaviours or styles decidedly more often than the less popular ones. Depending on the nature of the social environment, a specific set of adapted (assimilated) memes can contribute to an increase or decrease in the level adjustment of an individual. Thus, the "success" of a single meme or a set of memes is determined not only by the content but also by the environment, in which this content is externalized. The increase in the level of adaptation would then be synonymous with the increase in the level of acceptance of certain behaviours and their frequent imitation by the other members of the community. This is a situation analogous to biological evolution, where one phenotype can be beneficial in a variety of environmental conditions, while not in others.

\subsection{MEMES AND SERVICE QUALITY}

Parasuraman et al. (1988) define the concept of service quality as the difference between customer expectations and the experience resulting from the consumption of such a service. The potentially memetic nature of the quality of services is evidenced by its features, identical to the properties of memes (Shifman, 2013):

- object/content of services - understood as a comprehensive set of goods, obtained by the recipient of the service;

- a form of communication, which may be identical to the method of service realization;

- relationship/correlation between the provider and the recipient, i.e. the source and the recipient of the message (i.e. stance).

The subject, form, and relationship are the basic features of memes. At the same time, these elements, combined with the characteristic of the quality of services, which causes changes in the mental and the physical state of clients (Johnson, 1995), justify the memetic approach. Difficulties may also be caused by isolating a single meme, which, being a carrier of a particular meaning, affects the mental state change of the consumer. For further consideration, it is assumed that the quality of the service process is a conglomeration of memes, i.e. a memetic pool, by analogy with the genetic pool, as a set of genes in the population. Constructing a memetic pool can facilitate the 
analysis of the manner of the perception of service quality, the image of the reception area, etc.

The memetic content, emphasized with a varying intensity during the consumption of a service, can be reflected in the manner of perception of the quality of service. This feature is conditioned by the possibility of the transfer of memes between the members of the community. The transfer of the memetic content is carried out, among other ways, through the method of building a subjective perception of reality, and manifests itself in the method of conveying this content to the environment (Lisch, 2014). The content shared on the social networks is, in this case, the direct expression of the perception of reality by network users, and, therefore, also reflects their perception of the quality of a service.

\subsection{SOCIAL MEDIA AND THEIR CONNECTIONS WITH THE MEME THEORY}

The possibility of a direct and individual expression of the perception of reality is provided by the social media. Kaplan \& Haenlein (2010) define social media as online platforms enabling the creation of individual accounts, building a network of friends, as well as the creation and sharing of a variety of pieces of content (graphics, text, and multimedia). The content elements, to a large extent, consist of the so-called User Generated Content (UGC), i.e. the content created and shared by the users with other people. This content is used to obtain information on tourist attractions, services, the experiences of others, etc. (Sparks et al., 2013). Each of these elements contains some semantic meaning, which is read and absorbed by the recipient. Sometimes, certain content seems to exist in a veiled, hidden form. Kim \& Stepchenkova (2015) showed a significant influence of the so-called latent content, the elements not constituting the main plan of a photograph on the affective and cognitive activity of customers. Moreover, based on the obtained results, the authors confirm that the photos represent a set of attributes captured by the author, sent in the form of a photograph, and interpreted by the recipient. The emotional factor is also important with regard to the method of interpretation. Xu et al. (2015) argue that social media provide a platform for the presentation and transfer of emotions, which can have a positive, negative or neutral character (Li $\& \mathrm{Xu}, 2014)$. Choi \& Tom (2014) indicate the importance of the emotional component in the transfer of content via social networks. A similar approach is demonstrated by Highhouse et al. (2009), suggesting that through the proper formulation of the communication content, it is possible to control the impressions of the recipients of specific content. Using the desired pool of traits, this enables the formation of a particular perception of places, events, etc. At the same time, Kim \& Stepchenkova (2015) show that the recipients of the content "decode" their meaning in a way very similar to the organic image of a destination (Gartner, 1994), i.e. the one formed on the basis of the non-commercial sources of information. These sources are most likely related to the activities of local DMOs (Destination Management Organisations). They build a positive impression of a particular area, and at the same time create a mental, so-called "iconic" impression of the destination in the head of the customer.

\section{RESEARCH QUESTIONS AND THE DEVELOPMENT OF A HYPOTHESIS}

Su et al. (2015) suggest that customer-company identification, created by building mutual relationships, is one of the variables mediating between the perception of the quality of the product/service and the loyalty to a product/service as well as own wellbeing. Therefore, building high-quality services is one of the elements of relationship marketing, on the way to building customer confidence (Kim \& Cha, 2002). Relationship marketing deals with the establishment of partner relationships between the provider and the recipient to achieve individual goals through the exchange of certain values and the meeting of commitments (Grönroos, 1984). Replacing certain values, meanings, ideas, combined with the property of the quality of services, changing the physical and mental state of the recipients (Johnson et al., 1995) are the factors driving the use of the memetic approach in the analysis of perception and externalization of the quality of services. It is problematic, however, to transform the memetic content into measurable variables. With this in mind, the main research questions have been formulated:

- RQ1: Is it possible to construct a hypothetical memetic pool concerning the perception of the quality of certain services by a group of consumers?

- RQ2: Is it possible to divide the thus created memetic pool into the groups of attributes 
(memes) allowing for the examination of their incidence?

The aim of the study was to use the netnographic method (Jemielniak, 2013) to demonstrate the practical possibilities of using the model for the creation of the tourism image (Baloglu \& McCleary, 1999) to form, describe, and decompose the memetic pool related to the perception of the quality of certain services. Such a pool, as an effect of mental changes created due to the accommodation service consumption, has been developed based on the semantic analysis of the comments left on business cards of agrotourism farms located in the vicinity of the selected national parks in Poland, and the ones listed on the sites that compare offers for tourists.

The contents of the comments were referred to the cognitive-perceptual attributes of the model of the tourism image, grouped into three main factors (Baloglu \& McCleary, 1999):

- Factor I Experience: Cleanliness and hygiene of accommodation and catering; Quality of the available infrastructure; High quality of entertainment; Tasty cuisine; Good conditions for practicing recreation; Cosy accommodation; Interesting, Friendly People; Personal safety;

- Factor II Attractions: Historical monuments; Local handcraft; Cultural attractions; Mass events;

- Factor III: Environment: Clean, unpolluted environment; Beautiful, natural landscape; Attractive wild fauna and flora; Health-friendly climate

These are the indicators enabling the decomposition of the hotel service and its perception from the perspective of the quality of the process (Grönroos, 1984). From this perspective, the quality of the service is simultaneously reflected, among other things, in the mental state of the service recipient (Johnson et al., 1995), which can be externalized and transmitted, for example in the form of short entries on the sites comparing tourist offers. This latter feature allows for the examination of the quality of services from the perspective of the memetic approach (Dawkins, 1976).

The problematic issue, however, is the task of defining a meme itself. In the case of this study, it was assumed that a meme is a semantic reflection of the mental state of the recipient of the specific content. This condition, in turn, is externalized, among other ways, through the manner of expression of the opinion about a specific subject, product or service. The direct expression of the transfer and decomposition of fragments the memetic pool were the authorial entries of social network users, defined as UGC.

Another problem was to generate a point of reference and a tool, through the use of which it would be possible to decode and read the specific memetic content. In this paper, it is assumed that the use of the perceptual-cognitive component of the model of creating the tourist image (Baloglu \& McCleary, 1999) provides a basis for the creation of a memetic pool, as a set of memes relating to a particular service. At the same time, a collection created in that manner, can be easily decomposed. This distribution, in turn, allows for the analysis of the incidence of specific memes.

To gather as many comments as possible, the contents of five randomly selected comparison sites for tourist offers were analysed i.e. e-holiday.pl, nocowanie.pl, spanie.pl, emeteor.pl, and e-turysta. net. Due to the pilot nature of the research, the work included 12 of the 23 Polish national parks. In each of the comparison sites, with the use of the search engine integrated into the site, business cards have been identified relating to the agrotourism farms associated with each of the analysed national parks. The comments were archived with the use of Google spreadsheets. The contents of each comment were referred to the attributes grouped according to the three main factors mentioned above: experience, attractions, environment (based on Baloglu \& McCleary, 1999). A single comment can contain one or more semantic references to the attributes mentioned above. At the same time, each of them was seen by the author as a single meme. The study was conducted between January and March 2016.

\section{RESEARCH RESULTS}

During the conducted pilot research, 497 comments were identified. Out of these, 104 were related to the tourist lodging, located in the vicinity of Białowieski National Park (104), Biebrzanski National Park (45), Bieszczadzki National Park (31), Kampinoski National Park (21), Karkonoski National Park (19), Narwiański National Park (84), Ojcowski National Park (24), Roztoczański National Park (66), Słowiński National Park (19), Tatrzański National Park (8), Wigierski National Park (21), and Woliński National Park (55).

Using the three classification factors presented above, it was found that among the analysed comments, 1341 semantic and direct references were 
made to the attributes identified with the quality of service. This pool (Fig. 1) was dominated by the indications associated with Factor I, i.e. concerning the overall experience (1127, i.e. $83.9 \%)$. The second most frequently noted group of indications (193, i.e. $14.54 \%$ ) was related to the third factor, referring to the perception of the natural attributes in the immediate vicinity of the accommodation services (environment). The least numerous (21, i.e. $1.56 \%)$ were the indications relating to Factor II, describing the attributes associated with the local cultural heritage (attractions).
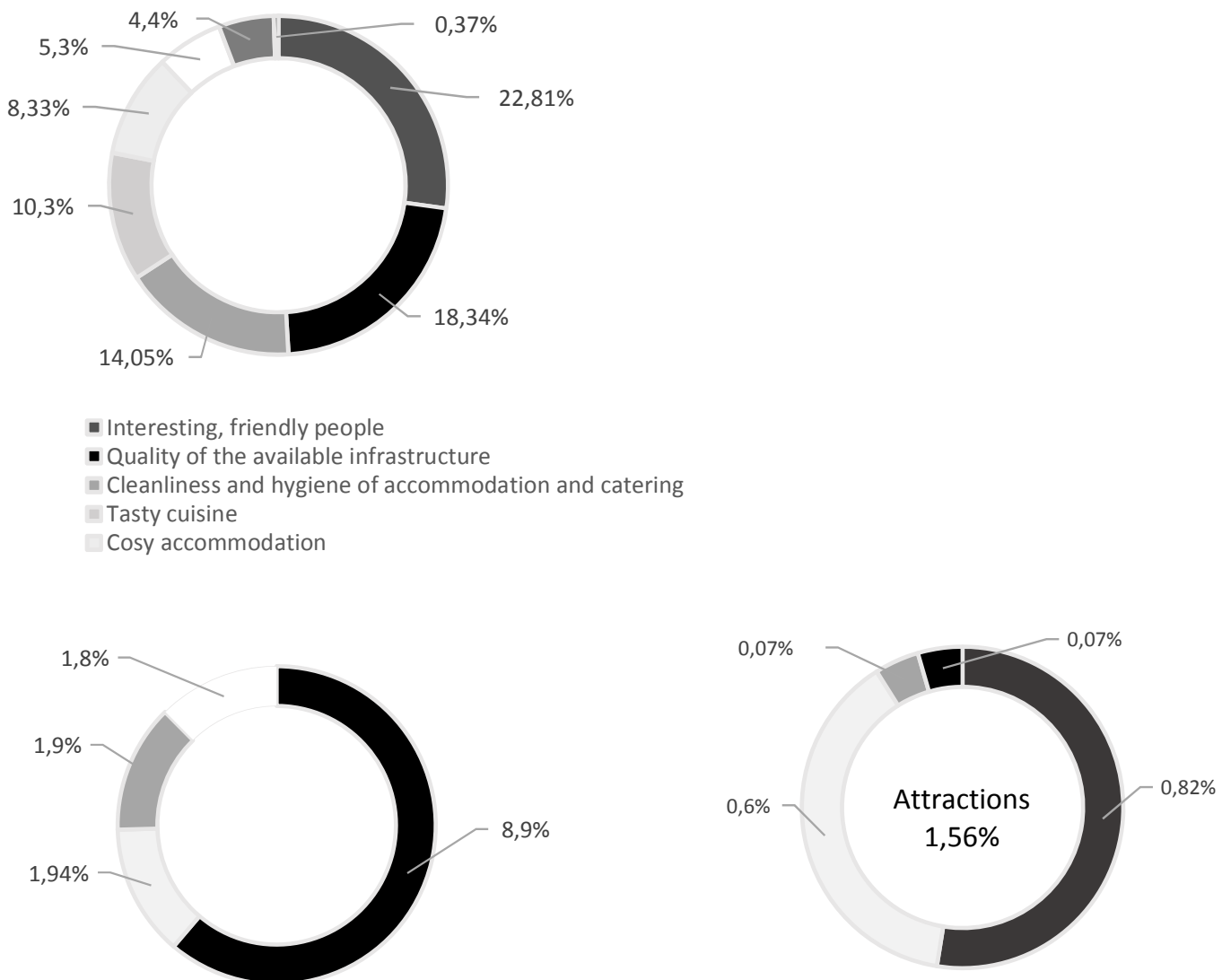

- Beautiful, natural landscape

- Clean, unpolluted environment
Attractive wild fauna and flora Health-friendly climate

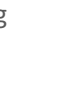

Fig. 1. Content of the memetic pool, reflecting the manner of perception of the quality of the accommodation service by its recipients from the perspective of the quality of the process

From the perspective of the first factor (experience), the dominant roles belong to the memes relating meaningfully to the friendly and welcoming service $(22.81 \%)$ and the quality of the available infrastructure (18.34\%). The least frequently represented factor is personal safety $(0.37 \%)$. The third factor (environment) was represented mainly by the references to the landscape (8.9\%). The semantic references to the second factor (attractions), was the least represented category of memes across the analysed memetic pool. Its share, not exceeding $2 \%$ of the total, relates mainly to historical monuments $(0.82 \%)$.

\section{DISCUSSION OF THE RESULTS}

The conducted studies have shown the ability to identify and analyse the memetic bank, relating to a particular phenomenon (quality of accommodation service). Therefore, it is possible to create a set of memes being the result of changes in the mental and emotional state of the consumer. In this case, the factor attributes of the formation model of tourist image by Baloglu \& McCleary (1999) were the tools of decomposition. A similar approach but without any 
indication of the memetic context was showed by Tiago et al. (2015). The authors analysed the contents of commentaries regarding the semantic links to the senses of sight, hearing, taste, and touch, demonstrating that the meaning of the comments refers not so much to taste and smell, but also to a number of other attributes e.g. visual effect, freshness of the ingredients, and healthiness of the meal. At the same time, these are the factors based on the direct experience of consumers, and, thus, positively affecting the scope of the spread of the content within the social network. Undoubtedly, the factor deciding about the increased coverage in this case is a positive emotional tone. The potential and positive impact of the transfer of experience through UGC in building the trust and making consumer decisions is also indicated by Bahtar \& Muda (2016).

The need to systematise and organise the data available within the social network is shown, among others, by Injadat et al. (2016). The authors particularly emphasize the unstructured nature of social media data, connected with different data types, such as text, images, and videos. Application of the theory of memes and the memetic bank as a collection of memes, allows for a simple systematisation of photographs, films and text elements, using common criteria. Assigning particular content to a single or several memes may be problematic, however, because of the subjective approach to categorizing.

Zhang et al. (2016) had an interesting debate, related in meaning to the theory of memes, although not referring directly to it, on the example of the financial markets. The authors argue that “... market can be partially predicted since people tend to accept messages which are confirmed by social environment and then invest according to what they have learned".

In this case, one may try to explain the transfer of the memetic content using the IPI (influence of Presumed Influence) theory. In the situation when a recipient of chosen content assumes that certain attitudes and behaviours presented in the transmission constitute a norm in a social (peer) group, there is a greater probability that they will be implemented by him/her (Gunther et al., 2006). From this perspective, building a high quality service is the transfer of information related to the "exceptional" nature of the specific service. The acquisition of such content by the recipient results in its further sharing. At the same time, the so-called "iconic" image of the provider is being built, setting out the way the provider is perceived by potential consumers. And, in turn, this implies a certain organic image of the provider, whose expression can be transferred. At the same time, certain expectations of the recipient in relation to the offered service are created. However, the analysis of the relationship between the perception of service quality and its impact on the formation of expectations regarding the quality of the service among future consumers requires a further detailed study.

D’Agostino et al. (2015) show that social networks are collections of hidden knowledge, relating to many fields of human activity. These authors distinguish general networks (Facebook), where the content on various aspects is collected, and specific networks (e.g. LinkedIn), associated with profiled areas of user activity. Therefore, it can be assumed that these networks are holistic or specific memetic banks, where takeover and replacement of certain memes take place. To some extent, this approach enforces the way of defining the memetic bank as a set of memes (present in the content elements) and transmitted across the network or beyond it. In turn, the nature of the network depends on the number of users, motives of their activities, interests, primary and secondary social bonds (Podgórecki \& Łoś, 1979). Also, the phenomenon of homophile, i.e., the integration of people with similar interests, is not without significance (Lazarsfeld, 1954). On the other hand, the occurrence of certain memes depends on the type of network and subject area, for which it exists.

At the same time, D'Agostino et al. (2015) compare the transfer of content within the $\mathrm{SN}$ to the physical process of diffusion. The memetic approach, in turn, transfers the level of the considerations similar to biological sciences and evolutionary phenomena. Such studies enable attempts to build scenarios for the development of the perception of the quality of services in the future, and the prediction of the potential distribution of the incidence of memes in a memetic pool concerning e.g. the quality of products or services.

Lymperopoulos \& Ioannou (2015) indicate that the impact (positive or negative) on the determination of the affective and behavioural activities of social network users is mainly exerted by self-generated bias, the online interactions, and the external environment. This approach is identical to the processes of exchange of genetic information in bacteria. Similar to these organisms, the users in the process of transformation, download information (memes) from the environment (other users, groups, associations of users, communities). This acquired piece of information is in the next type of information/meme 
flow process, i.e. conjugation is transmitted between the individuals and entities creating a social network.

Assuming that the quality of the process can be regarded as the so-called memetic pool (i.e. the total set of quantitative and qualitative attributes for describing the whole service process), it is possible to distinguish more expansive and less expansive memes (attributes) within it. The first category will dominate in the transmission to the recipient, while the other will constitute a subordinate element. The dominant memes will be identical to customer expectations, completed in the course of the consumption of the service. They will be transferred and/or processed (in the form of UGC). This transformation, from the perspective of a single recipient, may vary substantially in terms of quantity and quality. However, in the case analysis of a sample from the population (i.e. the analysis of the content of UGC and the memes externalized within them), it will create a ranking of the elements of the cultural transmission, which dominate the manner of perception of a service by the recipients. This, in turn, will provide a theoretical basis for the creation of strategies for building the quality of services while simultaneously building certain tourist expectations (Smoleński, 2011), as well as the tourist image (Tosun et al., 2015; Smoleński, 2010).

In summary, it has been shown that based on the semantic analysis of User Generated Content, is possible to construct a memetic bank, illustrating the manner of perceiving the accommodation service quality. To understand this phenomenon more thoroughly, we should carry out further research regarding the manner of creating the service quality by the service provider. Confronting the base bank, created by the service provider, with a bank, which was assimilated and externalized by recipients, would provide interesting results in the analysis of the effectiveness of the memetic content transfer.

\section{CONCLUSIONS}

The aim of the study was to demonstrate the potentially memetic nature of the quality of accommodation services. The quality of service, as perceived from the perspective of the quality of the process, was adopted as the theoretical basis. In this perspective, the manifestation of memetic transmission is the way of describing the quality of services by the recipients.

In this approach, the quality attributes of services form the memetic transmission, constituting a kind of a memetic pool. During service realization, but also indirectly during the image building of service providers in social networks, this transmission is transmitted in the direction of the recipients (current and potential). The result of the transmission is the perception of services and their quality through confrontation with the expectations of a service recipient (after using the service) or building the expectations themselves (before using the service). Subsequently, thanks to the properties of memes, an individual way of communication regarding the services and their quality is formed and expressed. This stage may be identified with the adoption of a specific subset - part of the meme pool, and the process of their transformation, i.e. individual transformations done by a single customer. The final stage will be the further transfer, i.e. to subsequent users through sharing, of a packet of memes in the UGC form.

The presented considerations, although supported by the results of partial studies, are theoretical in nature. They direct the research on the phenomenon of the quality of services to the population-evolutionary approach. The meme pools, described by the frequency of occurrence of individual memes, are dynamic, i.e. changing over time, depending on the external factors influencing the demand for certain products and services. At the same time, the chances for evolutionary success, defined as the stable presence on the market, pertain only to those services and related service providers, in the case of which the marketing activities and the process of service realization itself, are building the proper relationship with service recipients.

\section{ACKNOWLEDGEMENTS}

The research was carried out as part of the work No. S/ WZ/5/2015 on the Bialystok University of Technology and financed from Ministry of Science and Higher Education funds for the science.

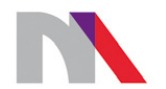

\section{Ministry of Science and Higher Education Republic of Poland}

7th International Conference on Engineering, Project, and Production Management (EPPM2016) was financed in the framework of the contract no. 712/P-DUN/2016 by the Ministry of Science and Higher Education from the funds earmarked for the public understanding of science initiatives.

7th International Conference on Engineering, Project, and Production Management (EPPM2016) finansowana 
w ramach umowy 712/P-DUN/2016 ze środków Ministra Nauki i Szkolnictwa Wyższego przeznaczonych na działalność upowszechniającą naukę.

\section{LITERATURE}

Bahtar, A. Z., \& Muda, M. (2016). The Impact of User Generated Content (UGC) on Product Reviews towards Online Purchasing - A Conceptual Framework. Procedia Economics and Finance, 37, 337-342. doi: 10.1016/S2212-5671(16)30134-4

Ball, J. A. (1984). Memes as replicators. Ethology and Sociobiology, 5(3), 145-161. doi: 10.1016/0162-3095(84) 90020-7

Baloglu, S., \& McCleary, K. W. (1999). A model of destination image formation. Annals of Tourism Research, 26(4), 868-897.

Blackmoore, S. (2000). The power of memes. Retrieved from http://www.psy.cmu.edu/ rakison/memes.pdf

D’Agostino, G., D’Antonio, F., De Nicola, A., \& Tucci, S. (2015). Interests diffusion in social networks. Physica A: Statistical Mechanics and its Applications, 436, 443-461. doi: 10.1016/j.physa.2015.05.062

Dawkins, R. (1976). The selfish gene. Oxford, England: Oxford University Press.

Dawkins, R. (1982). The extended phenotype. Oxford, England: Oxford University Press.

Gabora, L. (2013). An evolutionary framework for cultural change: Selectionism versus communal exchange. Physics of Life Reviews, 10(2), 117-145. doi: 10.1016/j. plrev.2013.03.006

Gartner, W. C. (1994). Image Formation Process. Journal Of Travel \& Tourism Marketing, 2(2-3), 191-216. doi: 10.1300/J073v02n02_12

Grönroos, Ch. (1984). A Service Quality Model and Its Marketing Implications. European Journal of Marketing, 18(4), 36-44. doi: 10.1108/EUM0000000004784

Gunther, A. C., Bolt, D., Borzekowski, D. L. G., Liebhart, J. L., \& Dillard, J. P. (2006). Presumed influence on peer norms: How mass media indirectly affect adolescent smoking. Journal of Communication, 56(1), 52-68. doi: 10.1111/j.1460-2466.2006.00002.x

Highhouse, S., Brooks, M. E., \& Gregarus, G. (2009). An organizational impression management perspective on the formation of corporate reputations. Journal of Management, 35(6), 1481-1493. http://doidx.org/10. $1177 / 0149206309348788$

Injadat, M. N., Salo, F., \& Nassif, A. B. (2016). Data mining techniques in social media: A survey. Neurocomputing, available online 23 June 2016. doi: 10.1016/j. neucom.2016.06.045

Jemielniak, D. (2013). Netnografia, czyli etnografia wirtualna - nowa forma badań etnograficznych [Netnography, or virtual ethnography, as a new form of ethnographic research]. Prakseologia, 154, 97-116.

Johnson, R. L., Tsiros, M., \& Lancioni, R. A. (1995). Measuring service quality: a systems approach. Journal of Service Marketing, 9(5), 6-19.
Juran, M. (1992). Juran on Quality by Design: The New Steps for Planning Quality into Goods and Services. New York, USA: The Free Press.

Kaplan, A. M., \& Haenlein, M. (2010). Users of the world, unite! The challenges and opportunities of Social Media. Business Horizons, 53(1), 59-68. doi: 10.1016/ j.bushor.2009.09.003.

Kim, H., \& Stepchenkova, S. (2015). Effect of tourist photographs on attitudes towards destination: Manifest and latent content. Tourism Management, 49, 29-41. doi: 10.1016/j.tourman.2015.02.004

Kim, W. G., \& Cha, Y. (2002). Antecedents and consequences of relationship quality in hotel industry. International Journal of Hospitality Management, 21(4), 321-338. doi: 10.1016/S0278-4319(02)00011-7

Knobel, M., \& Lankshear, C. A. (2007). Antecedents and consequences of relationship quality in hotel industry new literacies sampler. New York, USA: Peter Lang.

Lazarsfeld, P., \& Merton, R. K. (1954). Friendship as a social process: a substantive and methodological analysis, In M. Berger, T. Abel, C. H. Page (Eds.). Freedom and control in modern society. USA: Van Nostrand.

Lehtinen, U. L., \& Lehtinen, J. R. (1991). Two Approaches to Service Quality Dimensions. Service Industries Journal, 113, 287-303.

Li, W., \& Xu, H. (2014). Text-based emotion classification using emotion cause extraction. Expert Systems with Applications, 41(4), 1742-1749. doi: 10.1016/j.eswa. 2013.08.073

Lisch, R. (2014). Measuring Service Performance. Practical Research for Better Quality. Oxford, England: Routledge.

Lymperopoulos, I. N., \& Ioannou, G. D. (2015). Online social contagion modeling through the dynamics of Integrate-and-Fire neurons. Information Sciences, 320, 26-6. doi: 10.1016/j.ins.2015.05.004

Parasuraman, A., Zeithaml, V. A., \& Berry, L. L. (1988). SERVQUAL: a multiple-item scale for measuring consumer perceptions of service quality. Retailing: critical concepts, 64(1), 12-40.

Podgórecki, A., \& Łoś, M. W. (1979). Multi-Dimensional Sociology. England: Routledge \& Kegan Paul.

Shifman, L. (2013). Memes in a Digital World: Reconciling with a Conceptual Troublemaker. Journal of Computer-Mediated Communication, 18, 362-377. doi: $10.1111 /$ jcc4.12013

Smoleński, M. (2010). Wizerunek a lojalność turysty względem obszaru recepcji turystycznej [Destination's image and tourists' loyalty behaviors]. Ekonomia i Zarządzanie, 2(1), 38-51.

Smoleński, M. (2011). Atrybutowość produktu hotelowego w trzyczynnikowej teorii satysfakcji [The attributiveness of hotel product according to the three-factor theory of customer satisfaction]. Ekonomia $i$ Zarzadzanie, 3(1), 70-77.

Sparks, B. A., Perkins, H. E., \& Buckley, R. (2013). Online travel reviews as persuasive communication: The effects of content type, source, and certification logos on consumer behavior. Tourism Management, 39, 1-9. doi: 10.1016/j.tourman.2013.03.007 
Tiago, T., Amaral, F., \& Tiago, F. (2015). The Good, the Bad and the Ugly: Food Quality in UGC. Procedia - Social and Behavioral Sciences, 175, 162-169. doi: 10.1016/j. sbspro.2015.01.1187

Tosun, C., Dedeoğlu, B. B., \& Fyall, A. (2015). Destination service quality, affective image and revisit intention: The moderating role of past experience. Journal of Destination Marketing \& Management, 4(4), 222-234. doi: 10.1016/j.jdmm.2015.08.002

Urban, W. (2007). Definicje jakości usług - różnice oraz ich przyczyny [Definitions of service quality - differences and their reasons]. Problemy Jakości, 3, 4-9.

$\mathrm{Xu}, \mathrm{H}$., Yang, W., \& Wang, J. (2015). Hierarchical emotion classification and emotion component analysis on Chinese micro-blog posts. Expert Systems with Applications, 42(22), 8745-8752. doi: 10.1016/j. eswa.2015.07.028

Zhang, Z.-K., Liu, Ch., Zhan, X.-X., Lu, X., Zhang, C.-X. \& Zhang, Y.-Ch. (2016). Dynamics of information diffusion and its applications on complex networks. Physics Reports, 651, 1-34. doi: 10.1016/j.physrep.2016.07.002 